\title{
Surveying the Level of Perceived Freedom of University Students in their Leisure Time
}

\author{
Veli Ozan Çakır (Corresponding author) \\ Departmant of Sports Management \\ İstanbul University-Cerrahpasa, Istanbul, Turkey \\ E-mail: ozancakir@istanbul.edu.tr
}

Received: May 15, 2019 Accepted: June 20, 2019 Published: June 30, 2019

doi:10.5296/jei.v5i1.14786ＵRL: https://doi.org/10.5296/jei.v5i1.14786

\begin{abstract}
The purpose of this study is to investigate the level of perceived freedom of university students in their leisure time with respect to various parameters. The sample group of the study has been selected with purposive sampling method among Dumlupinar University PE and Sports College students with an average age of 22.49 \pm 2.76 , of whom 192 are male and 98 are female, with a total of 290 students. In the study, "Freedom Perceived in Leisure Time Scale" which has been developed by Witt and Ellis (1985) and adapted to Turkish by Lapa and Tercan (2017), has been used. To determine the personal information of participants percentage and frequency methods, and to determine whether the data has normal distribution or not Shapiro Wilks normality test has been conducted and once it has been concluded, that the data was suitable for parametric test conditions, independent $T$ Test and ANOVA Test has been used to analyse the data. Analysis shows, that with respect to gender, age, department, grade, and weekly leisure time sufficiency parameters there is no significant difference in perceived level of freedom, but with respect to welfare level and sports branch parameters there is a statistically meaningful difference. Consequently, it has been concluded, that in the perceived level of freedom of participants there are differences with respect to various parameters.
\end{abstract}

Keywords: University students, Leisure time, Perceived freedom in leisure time

\section{Introduction}

In a world, which is in constant progress and change, perhaps one of the few things which do not change and repetitively continue from the past are physical and mental qualities of individuals (Sevil et al., 2012; Demirel et al., 2017). In today's conditions one of the methods used to keep those two qualities healthy is leisure time and recreation events (Sevil et al., 
2012; Demirel et al., 2017). In parallel with this, the interest in recreational activities has increased. Recreation has gained importance for educational institutions and foundations. To be able to participate in recreational activities, an individual needs to have time left from work and compulsory needs. Recreation, with its good and positive affect on people, is a necessity due to the negative influence of today's urban and work environment. The need for recreation and the conveniences to satisfy this need are the results of industrialization and urbanization. Due to the insufficiency of outdoor recreation sources, people living in cities turn to outdoor recreation sources off cities. The deeds performed to reach recreation, or in other words, all the factors leading people to recreation, are defined as recreational activity. Recreation areas, likewise, could be defined as places where recreational activities take place. Some recreation areas are planned and designed to serve this purpose (public parks, playgrounds etc.) whereas others allow, due to the qualities they have, for recreational activities (Sar1, 2016).

Depending on where they take place and what purpose they serve, it is possible to categorize recreational activities as outdoor recreation, tourism recreation, health recreation, park recreation, recreational sports management, campus recreation, therapeutic recreation, workplace recreation and hospital recreation (Ardahan \& Lapa, 2011). Science, which defined utilizing spare time as recreation, has enabled people to be happy by letting them go beyond the ordinary, rest, have fun, and increase their work productivity (Karaküçük, 1997). The age of technology, along with many innovations that made life easier, has posed many problems for individuals and society as well. The comfort of doing many things without the help of others, tools which help people spare time and energy, fast transportation and such has led to antisocial lifestyle, inaction, obesity and many health problems. To cope with and even to defend against the negativity, which affects quality of live negatively as well, recreational activities engaged in leisure time is the best antidote (Arslan, 2013). In other words, leisure time activities help people be free from distress, improve themselves and thus, have a positive impact on themselves, their relationship with others, and their sociocultural adaptation (Serdar \& Ay, 2016; Iwasaki, 2007). People, for various reasons and expectations, want to spend their leisure time by taking part in leisure time activities indoors or outdoors, passively or actively, in urban or country environments. In this context it has been observed in many studies, that active participation in leisure time activities has positive influence on individuals. One of those influences is the concept perceived freedom (Lapa \& A Agyar, 2012). Perception of freedom in leisure time for an individual means willing participation in an activity, which the individual has deliberately chosen, and the feeling that comes with it (Siegenthaler \& O'Dell, 2000). And to be able to have maximum benefit from leisure time activities an individual needs to have proficiency, control experiences, take part in activities not with external, but with internal expectations (Lapa \& Ağyar, 2012).

In light of this information the purpose of the study is to determine the perceived level of freedom of university students, who participate in leisure time activities, with respect to various parameters. 


\section{Macrothink}

\section{Method}

\subsection{Research Model}

In the study survey model has been used. Survey model seeks to portray a past or current situation as it was or is, to define an event, an individual or an object on its own terms, and to observe it without trying to change current conditions (Karasar, 2012).

\subsection{Sample Group}

The sample group has been chosen by non-probability purposive sampling method among Dumlupinar University PE and Sports College students, who are 290 in total, of which 192 are male and 98 female, and with an average age of $22.49 \pm 2.76$.

\subsection{Data Collection Tools}

In this study "Personal Information Form," and "Perceived Freedom in Leisure Time Scale" have been used as data collection tools.

\subsubsection{Personal Information Form}

"Personal Information Form," which has been developed by the surveyors has been used to obtain information from the participants, such as gender, age, department, grade, sports branch, weekly leisure time sufficiency and welfare level.

\subsubsection{Perceived Freedom in Leisure Scale}

To survey the participants' perceived level of freedom in leisure time, "Perceived Freedom in Leisure Time Scale - 25," which has been developed by Witt and Ellis (1985), and adapted to Turkish by Lapa and Ağyar (2017), has been used. The scale is comprised of 25 articles and one dimension. In our study, the internal consistency coefficient of the scale has been observed to be 0.83 .

\subsection{Evaluating the Data}

Statistical analyses within the scope of the study have been conducted via SPSS 20 statistics package. To determine the personal information of participants descriptive statistics (frequency, arithmetic mean, standard deviation), to check whether the data has normal distribution or not Shapiro Wilks normalcy test has been conducted and once it has been confirmed that the data is suitable for parametric test conditions, to analyse the data independent $\mathrm{T}$ Test and ANOVA test have been used.

\section{Findings}

Table 1 displays statistical findings of participants with regards to gender, age, department, grade, weekly leisure time sufficiency, sports branch, and welfare level. Analysis shows, that of the participants $66.2 \%$ are "Female," 33.8\% are "Male," $53.1 \%$ are "21-23 years old," $26.9 \%$ study "Coaching," 33.8\% are "Juniors," $47.6 \%$ have average leisure time weekly, $46.9 \%$ have "Average" level of welfare, and $58.3 \%$ are engaged in "Team Sports." 
Table 1. Distribution of Participants' Personal Information

\begin{tabular}{|c|c|c|c|}
\hline Parameters & & $\mathrm{F}$ & $\%$ \\
\hline \multirow{3}{*}{ Gender } & Male & 98 & 33.8 \\
\hline & Female & 192 & 66.2 \\
\hline & Total & 290 & 100 \\
\hline \multirow{4}{*}{ Age } & $17-20$ & 72 & 24.8 \\
\hline & $21-23$ & 154 & 53.1 \\
\hline & 24 and Over & 64 & 22.1 \\
\hline & Total & 290 & 100 \\
\hline \multirow{5}{*}{ Department } & PE Teacher. & 76 & 26.2 \\
\hline & Coaching & 78 & 26.9 \\
\hline & Sports Management & 73 & 25.2 \\
\hline & Recreation & 63 & 21.7 \\
\hline & Total & 63 & 21.7 \\
\hline \multirow{5}{*}{ Grade } & Freshman & 95 & 32.8 \\
\hline & Sophomore & 44 & 15.2 \\
\hline & Junior & 98 & 33.8 \\
\hline & Senior & 53 & 18.3 \\
\hline & Total & 290 & 100 \\
\hline \multirow{4}{*}{ Weekly Leisure Time Sufficiency } & Insufficient & 59 & 20.3 \\
\hline & Normal & 138 & 47.6 \\
\hline & Sufficient & 93 & 32.1 \\
\hline & Total & 290 & 100 \\
\hline \multirow{4}{*}{ Welfare Level } & Low & 49 & 16.9 \\
\hline & Average & 136 & 46.9 \\
\hline & High & 105 & 36.2 \\
\hline & Total & 290 & 100 \\
\hline \multirow{3}{*}{ Sports Branch } & Team Sports & 169 & 58.3 \\
\hline & Individual Sports & 121 & 41.7 \\
\hline & Total & 290 & 100 \\
\hline
\end{tabular}

Table 2 displays $\mathrm{T}$ Test results of perceived freedom in leisure time with respect to participants' genders. Analysis shows, that there is no statistically significant difference in perceived freedom in leisure time with respect to participants' genders $(p>0.05)$. Perceived freedom of female participants is higher than that of male participants, but no significant 
difference has been observed.

Table 2. Perceived Freedom in Leisure Time Scale with Respect to Participants' Genders, T Test Results

\begin{tabular}{|l|l|l|l|l|l|}
\hline Scale & Gender & N & Avg. \pm Sd. & T & P \\
\hline \multirow{2}{*}{ PFL } & Male & 392 & $3.81 \pm 0.65$ & \multirow{2}{*}{-.617} & \multirow{2}{*}{.537} \\
\cline { 2 - 6 } & Female & 406 & $3.85 \pm 0.61$ & & \\
\hline
\end{tabular}

Table 3 displays ANOVA test results of perceived freedom in leisure time with respect to participants' ages. Analysis shows, that there is no statistically significant difference in perceived freedom in leisure time with respect to participants' ages ( $p>0.05)$. Level of perceived freedom in leisure time of participants between the ages of 21 and 23 is higher than that of other age groups but no significant difference has been observed.

Table 3. Perceived Freedom in Leisure Time Scale with Respect to Participants' Ages, ANOVA Test Results

\begin{tabular}{|l|l|l|l|l|l|}
\hline Scale & Age & N & Avg. \pm Sd. & F & P \\
\hline \multirow{4}{*}{ PFL } & $17-20$ & 72 & $3.78 \pm 0.62$ & & \\
\cline { 2 - 5 } & $21-23$ & 154 & $3.86 \pm 0.60$ & \multirow{3}{*}{.397} & \multirow{2}{*}{.673} \\
\cline { 2 - 4 } & 24 and Over & 168 & $3.84 \pm 0.67$ & & \\
\hline
\end{tabular}

Table 4 displays ANOVA test results of perceived freedom in leisure time with respect to participants' departments. Analysis shows, that there is no statistically significant difference in perceived freedom in leisure time with respect to participants' departments $(p>0.05)$. Perceived level of freedom of participants studying sports management is higher than that of those studying other subjects but no significant difference has been observed.

Table 4. Perceived Freedom in Leisure Time Scale with Respect to Participants' Departments, ANOVA Test Results

\begin{tabular}{|l|l|l|l|l|l|}
\hline Scale & Department & N & Avg. \pm Sd. & F & P \\
\hline \multirow{4}{*}{ PFL } & PE Teacher. & 76 & $3.83 \pm 0.60$ & & \\
\cline { 2 - 4 } & Coaching & 78 & $3.79 \pm 0.69$ & \multirow{3}{*}{1.312} & \multirow{2}{*}{.271} \\
\cline { 2 - 4 } & Sports Management & 73 & $3.96 \pm 0.59$ & & \\
\cline { 2 - 4 } & Recreation & 63 & $3.78 \pm 0.62$ & & \\
\hline
\end{tabular}




\section{Macrothink}

Table 5 displays ANOVA test results of perceived freedom in leisure time with respect to participants' grades. Analysis shows, that there is no statistically significant difference in perceived freedom in leisure time with respect to participants' grades $(p>0.05)$. Perceived freedom in leisure time of Senior students is higher than that of participants in other grades but not significant difference has been observed.

Table 5. Perceived Freedom in Leisure Time Scale with Respect to Participants' Grades, ANOVA Test Results

\begin{tabular}{|l|l|l|l|l|l|}
\hline Scale & Grade & N & Avg. \pm Sd. & F & P \\
\hline \multirow{4}{*}{ PFL } & Freshman & 95 & $3.75 \pm 0.65$ & & \\
\cline { 2 - 4 } & Sophomore & 44 & $3.79 \pm 0.67$ & \multirow{3}{*}{.710} & \multirow{2}{*}{.547} \\
\cline { 2 - 4 } & Junior & 98 & $3.86 \pm 0.60$ & & \\
\cline { 2 - 4 } & Senior & 53 & $3.93 \pm 0.56$ & & \\
\hline
\end{tabular}

Table 6 displays ANOVA test results of perceived freedom in leisure time with respect to participants' weekly leisure time sufficiency. Analysis shows, that there is no statistically significant difference in perceived freedom in leisure time with respect to participants' weekly leisure time sufficiency $(p>0.05)$. Perceived freedom in leisure time of participants with normal amount of leisure time is higher than that of participants in other groups but no significant difference has been observed.

Table 6. Perceived Freedom in Leisure Time Scale with Respect to Participants' Weekly Leisure Time Sufficiency, ANOVA Test Results

\begin{tabular}{|l|l|l|l|l|l|}
\hline Scale & WLT Sufficiency & $\mathrm{N}$ & Avg. \pm Sd. & F & P \\
\hline \multirow{4}{*}{ PFL } & Insufficient & 59 & $3.85 \pm 0.69$ & & \\
\cline { 2 - 4 } & Normal & 138 & $3.83 \pm 0.67$ & \multirow{3}{*}{.260} & \multirow{2}{*}{.772} \\
\cline { 2 - 4 } & Sufficient & 93 & $3.87 \pm 0.62$ & & \\
\hline
\end{tabular}

Table 7 displays ANOVA test results of perceived freedom in leisure time with respect to participants' welfare level. Analysis shows, that there is a statistically significant difference in perceived freedom in leisure time with respect to participants' welfare level $(p<0.05)$. Perceived freedom in leisure time of participants with a high level of welfare is higher than that of other participants. 
Table 7. Perceived Freedom in Leisure Time Scale with Respect to Participants' Welfare Level, ANOVA Test Results

\begin{tabular}{|l|l|l|l|l|l|}
\hline Scale & Welfare Level & $\mathrm{N}$ & Avg. \pm Sd. & F & P \\
\hline \multirow{4}{*}{ PFL } & Low & 49 & $3.78 \pm 0.68$ & & \\
\cline { 2 - 5 } & Average & 136 & $3.80 \pm 0.77$ & .341 & \multirow{2}{*}{$.037^{*}$} \\
\cline { 2 - 4 } & High & 105 & $3.96 \pm 0.51$ & & \\
\hline
\end{tabular}

Table 8 displays $\mathrm{T}$ Test results of perceived freedom in leisure time with respect to participants' sports branches. Analysis shows, that there is a statistically significant difference in perceived freedom in leisure time with respect to participants' sports branches $(p<0.05)$. Perceived freedom in leisure time of participants engaged in team sports is higher than that of participants engaged in individual sports.

Table 8. Perceived Freedom in Leisure Time Scale with Respect to Participants' Sports Branches, T Test Results

\begin{tabular}{|l|l|l|l|l|l|}
\hline Scale & Sports Branch & $\mathrm{N}$ & Avg. \pm Sd. & T & P \\
\hline \multirow{3}{*}{ PFL } & Team Sports & 169 & $3.90 \pm 0.60$ & \multirow{2}{*}{.456} & \multirow{2}{*}{$.050^{*}$} \\
\cline { 2 - 6 } & Individual Sports & 121 & $3.76 \pm 0.65$ & & \\
\hline
\end{tabular}

\section{Discussion}

In this study, the purpose has been to determine the level of perceived freedom of university students, when they participate in leisure time activities. Statistical analyses show, that there is no significant difference with respect to gender, but the study conducted by Emirin (2012), which surveys factors keeping people from participating in recreational activities, suggests that gender influences participation in recreational activities. The study conducted by Süzer (1997) suggests that Pamukkale University students spend their leisure time engaging in rather passive activities and their interest in sports is more on the side of viewership. Male students engage more actively in sports activities when compared to female students. But the study conducted by Serdar and Ay (2016), which surveys the satisfaction and level of perceived freedom in leisure time of university students, suggests that gender is not a difference creating parameter with respect to participation in leisure time activities. Results of that study have parallels with the data of our study. It is believed this result is due to the fact that today recreational activity areas are wider and it is possible to engage in many activities irrespective of gender. It has been observed that there is no significant difference in perceived level of freedom in leisure time activities with respect to participants' age parameter. The study conducted by Harmandar et al., (2017), also suggests that age parameter is not a significant difference creating parameter in participation in leisure time activities. It is 


\section{Ml Macrothink}

believed this result is mainly due to the fact that university students engage in leisure time activities regardless of age and that they have similar gains. In the perceived level of freedom in leisure time activities with respect to welfare level a significant difference has been observed. The study conducted by Lapa and Ardahan (2009), suggests that welfare level of university students have a negative influence on participation in recreational activities, and the study conducted by Dinçer and Çelik (2018), suggests that welfare level, mainly psychologically, influences leisure time satisfaction and therefore perceived level of freedom in leisure time. In the study conducted by Demirel and Harmandar (2009), significant differences were found between leisure time hindrances and monthly income levels. But in the study conducted by Çakır et al. (2018), which surveys leisure time management level of university students, suggests that there is no significant difference between leisure time management and welfare level of participants. It is believed this result is due to the fact that leisure time management could be associated with level of perceived freedom in leisure time activities, and therefore has no parallels with the results of our study.

As a result, there is no significant difference in perceived level of freedom in leisure time activities of university students with respect to gender, department, weekly leisure time sufficiency and grade parameters, but there is a significant difference with respect to welfare level and sports branch parameters.

In this context it is suggested that similar studies widen the sample group and apply the study to all departments, conduct quantitative and qualitative research methods, and determine the research pattern with a mixed method.

\section{References}

Ardahan, F., \& Lapa, T, Y. (2011). Açık Alan Rekreasyonu: Bisiklet Kullanıcıları ve Yürüyüşçülerin Doğa Sporu Yapma Nedenleri ve Elde Ettikleri Faydalar. Uluslar Arası İnsan Bilimleri Dergisi, 8(1).

Arslan, S. (2013). Serbest Zaman-Rekreasyon ve Serbest Zaman Eğitimi Kitabı. Nobel Yayın Dağıtım.

Çakır, O. V., Demirel, M., Demirel, H. D., \& Serdar, E. (2018). Üniversite Öğrencilerin Serbest Zaman Yönetimleri İle Yalnızlık Düzeyleri Arasındaki İlişki. Sosyal Bilimler Dergisi, 5(30), 452-460. https://doi.org/10.16990/SOBIDER.4565

Demirel, M., \& Harmandar, D. (2009). Üniversite Öğrencilerinin Rekreasyonel Etkinliklere Katılımlarında Engel Oluşturabilecek Faktörlerin Belirlenmesi. Uluslararası İnsan Bilimleri Dergisi, 6(1).

Demirel, M., Demirel, H. D., \& Serdar, E. (2017). Constraints and perceived freedom levels In the leisure of university students. Journal of Human Sciences, 14(1), 790-795. https://doi.org/10.14687/jhs.v14i1.4340

Dinçer, N., \& Çelik, E. (2018). Güneydoğu Anadolu Bölgesindeki Güreşçilerin Serbest Zaman Tatmin Düzeylerinin Çeşitli Değişskenler Açısından İncelenmesi. Tarih Okulu Dergisi, 11(2), 407-428. https://doi.org/10.14225/Joh1480 


\section{Macrothink}

Emir, E. (2012). Rekreatif Etkinliklere Katılımın Önündeki Engellerin Belilrlenmesi: Üniversite Ögrencileri Örneği. Karadeniz Teknik Üniversitesi Eğitim Bilimleri Enstitüsü Beden Eğitimi ve Spor Anabilim Dalı, Yüksek Lisans Tezi.

Harmandar Demirel, D., Demirel, M., \& Serdar, E. (2017). University students' opinions of the meaning of leisure and their perceived freedom in leisure. Journal of Human Sciences, 14(1), 796-802. https://doi.org/10.14687/jhs.v14i1.4341

Iwasaki Y. (2007). Lesiure and quality of life in an international and multicultural context: what are major pathways linking leisure to quality of life. Social Indicators Research, 82, 233-264. https://doi.org/10.1007/s11205-006-9032-z

Karaküçük, S. (1997). Rekreasyon Boş zamanları Değerlendirme Kavram, Kapsam ve Bir Araştırma. Seren Ofset, Ankara.

Karasar, N. (2012). Bilimsel Araştırmalar Yöntemi. Ankara: Nobel Yayınları.

Lapa, T. Y., \& Ağyar, E. (2012). Üniversite Öğrencilerinin Serbest Zaman Katılımlarına Göre Algılanan Özgürlük. Hacettepe Spor Bilimleri Dergisi, 23(1), 24-33.

Lapa, T. Y., \& Ardahan, F. (2009). Akdeniz Üniversitesi Öğrencilerini Serbest Zaman Etkinliklerine Katlım Nedenleri ve Değerlendirme Biçimleri. Hacettepe Spor Bilimleri Dergisi, 20(4), 132-144.

Lapa, Y. T., \& Tercan, E. T. (2017). Serbest Zamanda Algllanan Özgürlük Ölçeği: Yapı Geçerliğinin Sınanması. World Congress of Sport Sciences Researches, November 23-26, 2017, Manisa, Turkey.

Sarı, C. (2016). Altınyaka (Antalya) Yolunun Rekreasyonel Aktiviteler İçin Kullanımı ve Alanının Potansiyelinin Belirlenmesine Yönelik Bir Saha Araştırması. SDÜ Fen Edebiyat Fakültesi Sosyal Bilimler Dergisi, 39, 117-132.

Serdar, E., \& Ay, M. S. (2016). Üniversite Öğrencilerinin Katıldıkları Serbest Zaman Etkinliklerinden Tatmin Olma ve Algılanan Özgürlük Düzeylerinin İncelenmesi. İstanbul Üniversitesi, Spor Bilimleri Dergisi, 6(2).

Sevil, T., Şimşek, Y. K., Katırcı, H., Çelik, O. V., Çeliksoy, A. M., \& Kocaekşi, S. (2012). Boş Zaman ve Rekreasyon Yönetimi. T. C. Anadolu Üniversitesi Yayını (No. 2497).

Siegenthaler, K. L., \& O’Dell, I. (2000). Leisure Attitude, Leisure Satisfaction and Perceived Freedom in Leisure Within Family Dyads. Leisure Sciences, 22, 281-296. https://doi.org/ $10.1080 / 01490409950202302$

Süzer, M. (1997). Üniversite Öğrencilerinin Sosyal ve Ekonomik Özelliklerine Göre Boş Zaman Faaliyetlerini Değerlendirme Biçimleri (Pamukkale Üniversitesi Örneği). Yayınlanmamış Yüksek Lisans Tezi, Hacettepe Üniversitesi, Sosyal Bilimler Enstitüsü.

Witt, P. A., \& Ellis, G. D. (1985). Development of a short form to asess perceived freedom in leisure. Journal of Leisure Research, 17(3), 225-233. https://doi.org/10.1080/00222216.1985. 11969632 


\section{Copyright Disclaimer}

Copyright for this article is retained by the author(s), with first publication rights granted to the journal.

This is an open-access article distributed under the terms and conditions of the Creative Commons Attribution license (http://creativecommons.org/licenses/by/3.0/). 